\title{
MULTIVARIATE ANALYSIS MODEL IN MEASURING THE LEVEL OF THE EFFICIENCY ISLAMIC BANKING INDUSTRY
}

\author{
Willyanto Kartiko Kusumo \\ Muljono
}

Faculty of Economics, Semarang University (USM)

\begin{abstract}
Efficiency is one of the performance parameters underlying an organization. Efficiency in the world of banking is one of the performance parameters that is quite popular and widely used because it is the answer to the difficulties in calculating banking performance measurements. The measurement of banking efficiency can be done with Multivariate Analysis. Multiveriate is a methodology for determining relative efficiency and managerial performance based on empirical data. In this method, profit is modeled to be deviated from its profit efficient frontier which is influenced by the input and output functions. The sample of this study was 40 Islamic Commercial Banks and Islamic Business Units for 4 years starting from 2014-2018 which were analyzed using the STATA 8 technique with panel data. The results of this research show that Islamic banks are technically efficient based on intermediation (100\%) and the efficient scale based on intermediation and production. Efficiency can be increasing liquid assets, while based on production approach.
\end{abstract}

Keywords : Efficiency; Financial performance; Profitability, Islamic Bank Industry.

${ }^{1}$ willyanto@usm.ac.id; Faculty of Economics, Semarang University

${ }^{2}$ sastro@usm.ac.id; Faculty of Economics, Semarang University 


\section{INTRODUCTION}

The development of Islamic banking in Indonesia has experienced significant increase, this is what underlies the establishment of laws governing Islamic banking, namely Act No. 21 year 2008. In the act, it is explained in chapter 1 article 1 concerning general provisions that distinguishes conventional banks and Islamic banks clearly. Islamic banking business in carrying out its functions is to collect funds from customers and distribute financing based on the contracts contained in the Islamic economy, such as mudharabah, wadi'ah, musyarakah, mudabahah, or other contracts that do not conflict with Islamic law.

Table 1.

The Development of the Amounts and Offices Islamic Banking

\begin{tabular}{|l|c|c|c|c|c|}
\hline \multirow{2}{*}{ The Amount of Islamic Banking } & \multicolumn{5}{|c|}{ Year } \\
\cline { 2 - 6 } & $\mathbf{2 0 1 4}$ & $\mathbf{2 0 1 5}$ & $\mathbf{2 0 1 6}$ & $\mathbf{2 0 1 7}$ & $\mathbf{2 0 1 8}$ \\
\hline $\begin{array}{l}\text { Number of Islamic Commercial Banks } \\
\text { (SCB) }\end{array}$ & 11 & 11 & 12 & 12 & 14 \\
\hline Number of Islamic Business Units & 24 & 23 & 22 & 22 & 21 \\
\hline Number of Islamic BPR & 158 & 163 & 163 & 163 & 165 \\
\hline $\begin{array}{l}\text { Number of SCB, SBU and Islamic } \\
\text { BPR }\end{array}$ & 193 & 197 & 197 & 197 & 197 \\
\hline $\begin{array}{l}\text { Number of offices of SCB, SBU and } \\
\text { BPRS }\end{array}$ & 1.835 & 2.990 & 2.910 & 2.845 & 2.746 \\
\hline $\begin{array}{l}\text { Number of Islamic Services from SBU } \\
\text { Number of SCB + SBU DPK }\end{array}$ & 1.277 & 1.277 & 1.784 & 1.846 & 1.846 \\
\hline $\begin{array}{l}\text { Nump. Billion) } \\
\text { (Rp. }\end{array}$ & 147.512 & 183.534 & 217.858 & 243.565 & 265.113 \\
\hline Total of Labor (SCB, SBU, BPRS) & 31.578 & 39.545 & 43.054 & 45.627 & 46.174 \\
\hline SourCe: Islamic Banking Statistics, 2018 & & & \\
\hline
\end{tabular}

Source: Islamic Banking Statistics, 2018

The rapid development of Islamic banks has provided evidence that even though the world is hit by a crisis but the performance of Islamic banks remains good where Islamic bank assets in the last five years on average grew more than 43 percent. Since the enactment of Act No.21 year 2008, the development of the national Islamic banking industry increasingly has an adequate legal basis to encourage the growth of Islamic banking industry and support the national economy. From table 1, it can be seen that the number of Mandiri Islamic Bank (SCB) and Islamic Business Units (SBU) offices is experiencing rapid growth. In the period of 2014 to 2018 the number of SCB increased and the number 
of offices increased by 2.746 offices. Whereas SBU has decreased by 4 SBU because several SBU have established themselves as SCB, but the remaining SBU still survive.

Table 2.

The Development of Islamic Banking Performance in Indonesia

\begin{tabular}{|l|c|c|c|c|c|}
\hline \multirow{2}{*}{\multicolumn{1}{|c|}{ Annotation }} & \multicolumn{5}{c|}{ Year } \\
\cline { 2 - 6 } & $\mathbf{2 0 1 4}$ & $\mathbf{2 0 1 5}$ & $\mathbf{2 0 1 6}$ & $\mathbf{2 0 1 7}$ & $\mathbf{2 0 1 8}$ \\
\hline Return On Equity (ROE, \%) & 25.81 & 17.58 & 15.73 & 24.06 & 17.24 \\
\hline Capital Adequacy Ratio (CAR, \%) & 10.77 & 16.25 & 16.63 & 14.13 & 14.44 \\
\hline Non Performing Finance (NPF, \%) & 1.84 & 3.02 & 1.34 & 1.34 & 1.75 \\
\hline $\begin{array}{l}\text { Operating Costs Operating Income } \\
\text { (OCOI, \%) }\end{array}$ & 84.39 & 80.54 & 85.63 & 82.51 & 83.40 \\
\hline Financing to Deposit Ratio (FDR, \%) & 89.70 & 89.67 & 88.94 & 100.00 & 100.32 \\
\hline Financing (in billion) & 46.886 & 68.181 & 102.655 & 147.505 & 184.122 \\
\hline Assets (in billion) & 66.090 & 97.519 & 145.466 & 195.017 & 242.276 \\
\hline Third Party Funds (TPF, in billion) & 147.512 & 183.534 & 217.858 & 243.565 & 265.113 \\
\hline
\end{tabular}

Source: the report on the development of Islamic finance in 2016

A fairly good and significant development of Islamic banks has an impact on the number of the bank assets.In this case, Islamic banks are also required to be able to deliver the customers' excessive funds to customers who need funds effectively and efficiently. Effective means the accuracy of providing funding to those who need it, while efficient means the suitability of the results between the input used and the output produced which is described by good level of efficiency, because the efficiency is a performance parameter which is theoretically one of the measurements underlying all performances with maximum output or getting minimum input level with certain level of output. From table 2, it can be seen that Islamic banking experienced rapid growth from 2014 to 2018, the financial ratio indicators such as ROE, CAR, NPF, OCOI and FDR experienced fluctuative development during that period. The highest ROE value occured in 2014 , namely $25.81 \%$, after that this ratio was below $30 \%$. It indicated that the greatest level of profit achieved was in 2014. The highest CAR value occurred in 2016 which was $16.63 \%$. The value of CAR decreased in 2017 by $2.5 \%$, but it could increase again in 2018 . The BOPO value that was the closest to optimal efficient was in 2016 which was $85.63 \%$. The decrease of BOPO value occurred in 2015 and 2017, which was $3.85 \%$ in 2015 and $3.12 \%$ in 2017, but this ratio increased again in 2016 by $0.89 \%$. 
The highest NPF occurred in 2015 which was 3.02\% and the lowest occurred in 2016 and 2017 which was 1.34\%. Islamic bank FDR shows an increase each year, in 2017 and 2018 period FDR can reach 100\%, indicating that Islamic banks can achieve FDR efficiency optimally. While the value of Financing, Assets and TPF increased continuously from 20142018 period. The highest financing occurred in 2018, which amounted to 184.122 billion, the highest number of Islamic banking assets was also in 2018, amounting to 242.276 billion, as well as the highest number of TPFwas in 2018 of 183.534 billion.Banking performance can be measured using one of the parameters, namely efficiency. The efficiency level of a bank can reflect the extent to which a company manages resources to be used optimally. Efficiency is the comparison between output and input. Optimal efficiency is the best comparison between output and input. Input is translated as sacrifice issued while output is translated as the result of sacrifices that have been issued.The relationship between structure, behavior and performance is now a two-way relationship that affects each other. This means that industry performance can influence company behavior and company behavior can influence market structure. Theory of Multivareate Analysis believes that market structure will affect the performance of an industry. According to Burgess (2008), to analyze the banking industry variables relevant to the banking industry observed that do have different characteristics from the industry in general are needed. The paradigm that has been updated is then applied to the analysis of Islamic banking industry.

\section{Efficiency Measurement Technique}

Efficiency measurement can be done through several approaches, including by using ratio approach, namely measuring the performance of banks using accounting standards and the regression approach. This approach measures the level of efficiency by using the model from certain level of output as a function of various input levels. The regression function is as follows:

\section{$\mathbf{Y}=\mathbf{f}(\mathbf{X 1}, \mathbf{X 2}, \mathbf{X 3}, \mathbf{X} 4, \ldots \ldots . . . \mathrm{Xn})$}

In which: $\mathrm{Y}=$ Output and $\mathrm{X}=$ Input

The regression approach will produce estimation of relationship that can be used to produce the level of output produced by an Economic Activity Unit (EAU) at a certain input level. EAU can be said to be efficient if it produces more output than the estimated output. 


\section{Input Oriented Measurement}

This illustration of measurement can be illustrated by a simple example in the case of a particular company that uses two inputs ( $\mathrm{x} 1$ and $\mathrm{x} 2$ ) to produce a single output (y) with an assumption of CRS (Constant Return to Scale). Isoquant SS describes the combination of inputs to produce the same level of output (technically efficient). The OP line shows the combination of inputs used by a company. Point Q shows efficiency technically and allocatively. Point $\mathrm{P}$ shows inefficiency because it is not on the isocost and isoquant curves. Point R shows efficiency allocatively while Q shows efficiency technically.

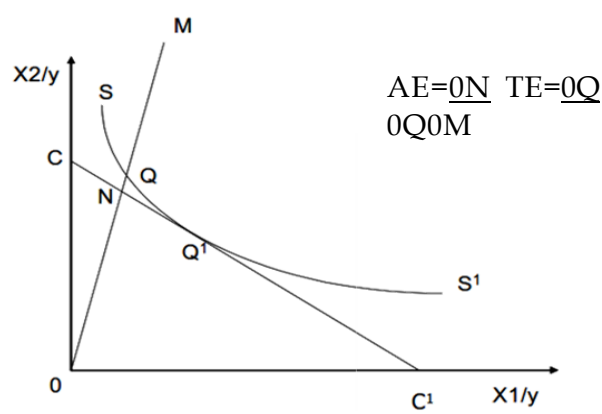

Note : AE: Allocative Efficiency; TE: Technical Efficiency $\mathrm{x} 1$ = first input, $\mathrm{x} 2=$ second input, $\mathrm{y}=$ output

Figure 1.

\section{Technical Efficiency and Allocative Efficiency}

In Figure 1, it appears that the company uses a certain number of inputs, namely point $\mathrm{M}$ to produce one unit of output. Companies that are technically inefficient will be along the QM point when all inputs can be reduced proportionally without reducing the amount of output. Generally this is represented by a percentage which is the ratio between QM / OM when all inputs can be reduced. The technical efficiency company is calculated based on the ratio between OQ and OM.

$\mathrm{TEI}=\mathrm{OQ} / \mathrm{OM}$, or equal to $1-\mathrm{QM} / \mathrm{OM}$

$0<$ TEI $<1$ (Indicator of the company efficiency level)

I shows the input oriented measurement. If TEI $=1$, it indicates that the company is an efficient company, for example point $\mathrm{Q}$ when $\mathrm{TEI}=1$ because point $\mathrm{Q}$ is on the isoquant line. If the ratio of input to price is represented by the $\mathrm{CC} 1$ line, it can be used to calculate allocative efficiency. The allocative efficiency of a company operating at $\mathrm{p}$ (certain) price level is defined as the ratio of $\mathrm{ON} / \mathrm{OQ}$. 
$\mathrm{AEI}=\mathrm{ON} / \mathrm{OQ}$

Along the NQ line shows the reduction of production costs that occurs if allocative or

$\mathrm{EEI}=\mathrm{ON} / \mathrm{OM}$

technical efficiency occurs at point Q so that economic efficiency can be formed which is the

Ratio of:

when NM can be represented as the reduction of production costs. For annotation, technical and allocative efficiency shapes

$\mathrm{TEI} X \mathrm{AEI}=\mathrm{OQ} / \mathrm{OM} \mathrm{XON} / \mathrm{OQ}=\mathrm{ON} / \mathrm{OM}$ economic efficiency.

All efficiency values are between zero and one.

\section{Output-Oriented Measurement}

Output orientation measures when a number of outputs can be increased proportionally without changing the number of inputs used which can be seen in Figure 2 below:

(a) DRTS

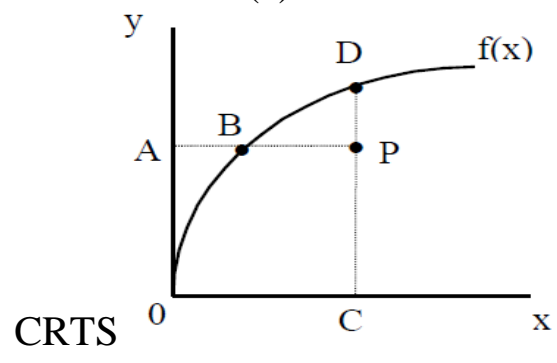

Source: Tim Coelli (2006:7) (b)

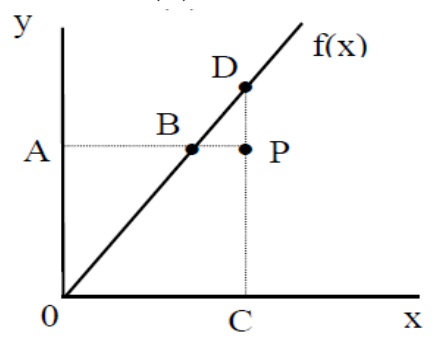

Figure 2.

Measurement of Output Input Oriented

\section{Efficiency and Return to Scale}

Input and output oriented measurements will produce the same measurement value from technical efficiency if they are in the Constant Return Scale (CRS) condition. The result of TE measurement value will not be the same. This example is depicted in Figure 3 where the 
ZZ line 'is a production possibility unit curve and point $\mathrm{A}$ can be compared with an inefficient

company

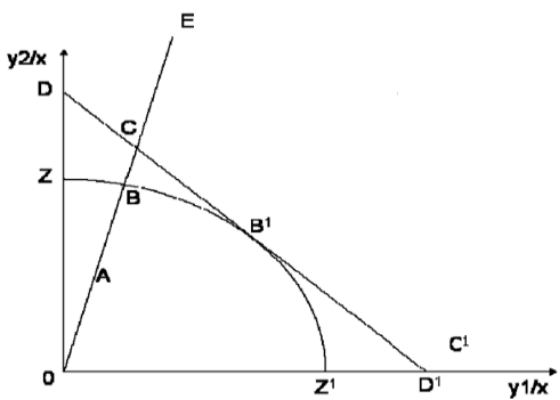

Source: Tim Coelli (2016: 7)

Figure 3.

Technical and Alocative Efficiency with Output Orientation

Points A and B1 in Figure 3 above explain the scale of efficiency produced by companies A and B1. The ZZ1 curve is a production possibility curve that shows efficiency technically. DD1 curve describes the isorevenue curve (allocatively efficient). Points B and B1 describe efficient technically because they are located on the isoquant. CB1 is allocatively efficient because it is located on DD1 isorevenue. B1 is technically efficient and allocative. Points OE indicate the combination of output produced by the company. Point $\mathrm{A}$ is technically and allocatively inefficiency point because it does not lie in ZZ1 and DD1. AB is inefficiency technically which means that output can be increased to B without additional input. Calculation of technical efficiency with the output approach is the ratio of OA / OB. Isorevenue is a line that describes the combination of output produced by a company with the same level of income. Allocative efficiency is obtained through $\mathrm{OB} / \mathrm{OC}$ ratio. When it is combined, it becomes the economic efficiency of OA / OB X OB / OC $=\mathrm{OA} / \mathrm{OC}$.

\section{Factors Affecting Efficiency}

PBI No.9/1/PBI/2007 states that the soundness of the bank is the result of qualitative and quantitative assessments on various factors that influence the condition or performance of a bank. These factors include capital, asset quality, profitability, liquidity, and sensitivity to market risk and management factors. The calculation guidelines for each of these ratios have been regulated in SE BI No.6 /23/DPNP dated May 31, 2004. Empirically, the results of Lukman Dendawijaya's (2013) research concluded that factors which are thought to influence efficiency among others: ROA, CAR, FDR, BOPO, PPAP, NPF. 
Various studies related to banking efficiency with SCP approach have been carried out, namely: Yudistira's research (2013) analyzes the level of efficiency in Islamic banks by conducting empirical analysis of 18 different banks spread throughout the world. The method used in this study is the Financial Ratios in relation to Capital, Asset and Liquidity of Islamic banks with input variables in the form of staff costs, fixed assets, total deposits and output variables in the form of total loans, other income, liquid assets. Their research concluded that the level of inefficiency in Islamic banks was relatively low at around 10\% compared to conventional banks. The performance of Islamic banks was affected by the global crisis but then went very well after a difficult period.

Hadad, Santoso, and Mardanugraha's research (2013) used the Camel Rating System approach. Determination of input-output variables in this study uses cost analysis approach. The variables used in this study include labor costs, price of funds as input and credit variables given by the parties related to banks, credit given to other parties, securities held as output variables. The results of their research suggest that mergers do not all increase efficiency, mixed foreign banks become the most efficient banks and in 2012 the national foreign exchange private bank was the most efficient bank.

Sufian's research (2012) measured the relative efficiency level between foreign Islamic banks and domestic Islamic banks in Malaysia. The variables used in this study were total deposts, labour, and fixed assets as input variables and total loans, and income as output variables. The results of his research revealed that Malaysian Islamic banking experienced a decline in efficiency. Domestic Islamic banks have a slightly higher level of efficiency than foreign Islamic banks. Muharam and Pusvitasari's research (2012) used the input variables: savings and other operating costs, while the output variables were financing, current assets, and other operating income. The samples used in their research were Islamic banks. The results of their research stated that there was no difference in efficiency value between state-owned banks and non-state-owned banks, and there was no difference in the efficiency value of nonforeign exchange private banks and the foreign exchange banks during the period of observation.

Ascarya and Yumanita's research (2012) measured and compared the level of Islamic banks efficiency in Malaysia and Indonesia using the Parametric method. The variables in their research were total deposits, labour, and assets as input variables and loans, and income as output variables. The results of their research showed that Islamic banks in Indonesia experienced a greater increase in asset value compared to the Islamic banks in Malaysia. 
Muhamad, Hassan, and Badar (2014) examined the comparison of cost efficiency and profit of Islamic and conventional banks in the 21 countries of the Islamic Organization Conference (IOC). Their research used labour, fixed assets, and total funds as input and total loans, 
otherearnings assets, and off-balance sheet items as output. Johnes, Izzeldin, and Pappas (2014) examined the efficiency differences between Islamic banks and conventional banks in GCG countries member using the financial ratio approach. The input variables used were deposits and short term funding, fixed assets, general and administrative expense, and equity. Output variables used were total loans and other earning assets. By using financial ratio, it is known that cost efficiency in Islamic banks was lower than the conventional banks.

Based on the explanation described above, the expected goals in this study are to determine the effects of Return On Assets (ROA),Capital Adequacy Ratio (CAR),Financing Deposit Ratio (FDR), Operating Costs Operating Income (OCOI), Allowance for Productive Current Asset (APCA), Non Performing Finance (NPF) on the efficiency of Islamic banking with the Structure Conduct Performance (SCP) approach and whether there are differences in efficiency values in Islamic banking in carrying out their activities and operations seen from the input and output components. The renewal in this study lies in the method used in determining input and output with the Multivariate Analysis approach.

\section{METHOD, DATA AND ANALYSIS}

This research on Islamic Banking Industry Structure, Behavior and Performance will discuss some determinants of market structure and behavior of Islamic banking industry as well as the relationship between the three. The structure variables that will be discussed include the ratio of concentration (assets) which is influenced by market share (TPF), Islamic banks performance behavior variables and dummy variables. The behavioral variables to be discussed are promotional behavior (advertence intensity), which is influenced by financing behavior (FDR), structural variables, Islamic banks performance and dummy variables. Dummy variables are to represent the economic conditions, namely economic crisis situations and normal situations. The samples of this study were 40 Islamic banks consisting of 16 Islamic Commercial Banks and 24 Islamic Business Units with observation periods starting from 2014 to 2018. The analysis used SCP approach using the STATA 8 technique with panel data. First, the banking industry structure approach to assess how far the structure of the banking industry based on the concentration ratio of Islamic banking. The choosing of the approach method is strongly related to the type of Islamic banking market that cannot be classified into a perfectly competitive market but is more likely to be in the imperfect competition market. 


\section{RESULT}

\section{Market Structure}

Based on asset concentration, an average concentration of 70.13 percent was obtained. The average CR4 value of 70.13 shows that the market structure of the Islamic banking industry is a strict oligopoly. The development of the market structure of the Islamic banking industry which is still high above 70 percent shows6that the market structure of the Islamic banking industry is still in the strict oligopoly category. Since 2014, the structure of the banking industry has become a full oligopoly. In this period, the leading bank was able to determine the rate of return, but the birth of new banks, the results of the conversion of Islamic business units (SBU) into Islamic commercial banks (SCB), such as Islamic BNI, Islamic BRI, Bukopin Islamic Bank, Panin Islamic Bank, Islamic BCA and other banks that were established until 2014 (Table 2), caused the constellation of the structure of the Islamic banking industry to turn into monopoly competition, which is entering 2013 until now. Furthermore, the changing market share of Islamic banks from oligopolistic to monopolistic competition also experienced a decline in market share.

Table 3.

Concentration Level (CR4) and Market Share (MS) of Islamic Banking Industry, 2014-2018

\begin{tabular}{|c|c|c|l|}
\hline Year & MS & CR4 & Market Structure \\
\hline 2014 & 74.59 & 66.62 & Strict Oligopoly \\
\hline 2015 & 71.83 & 65.29 & Monopolistic Competition \\
\hline 2016 & 66.54 & 61.06 & Monopolistic Competition \\
\hline 2017 & 64.92 & 59.77 & Monopolistic Competition \\
\hline 2018 & 58.87 & 58.84 & Monopolistic Competition \\
\hline
\end{tabular}

Source: processed from various sources (Asngari, 2018).

Descriptive statistics were performed to show the amount of data $(\mathrm{N})$ used in this study, as well as to show the maximum values, minimum values, mean values, and standard of deviations of each variables held by Islamic Commercial Banks and Islamic Business Units which became the object of this research. This study intends to examine the effects of factors proxied to Return On Assets (ROA), Capital Adequacy Ratio (CAR), Financing Deposit Ratio (FDR), OperatingCosts Operating Income (OCOI),Allowance for Productive Current 
Assets (APCA) and Non Perfirming Finance (NPF) as the independent variables on the level of Efficiency as the dependent variables. The results of the calculation of descriptive statistics are as follows:

Table 4

Descriptive Statistics Results

\begin{tabular}{|l|c|c|c|c|c|}
\hline & N & Min. & Max. & Mean & Std. Dev. \\
\hline ROA & 40 & -1.55 & 4.13 & 1.3733 & .94668 \\
\hline CAR & 40 & 10.74 & 100.63 & 21.0095 & 14.75106 \\
\hline FDR & 40 & 74.14 & 271.88 & 96.7049 & 24.65569 \\
\hline OCOI & 40 & 50.76 & 134.10 & 83.2735 & 11.46296 \\
\hline APCA & 40 & 35.90 & 138.53 & 104.998 & 11.80604 \\
\hline NPF & 40 & .00 & 6.76 & 2.5365 & 1.57253 \\
\hline Valid N (listwise) & 40 & & & & \\
\hline
\end{tabular}

Source: Processed data, 2018

The descriptive statistics results in Table 3 show that the Return on Assets (ROA) variable has the standard set by Bank Indonesia in PBI No. 6/9 / PBI / 2004 amounting to 1.5\%. From the available data, the lowest (minimum) ROA value is $-1.55 \%$. While the highest (maximum) ROA value is $4.13 \%$. By looking at the average value of ROA of $1.37 \%$, it shows that bank ROA during the study period is below the standard of Bank Indonesia. The standard of deviation shows a value of $0.94 \%$, so that the ROA data in the observation period can be said to be good, because the standard of deviation value is lower than the average value. Capital Adequacy Ratio (CAR) variable has the standard set by Bank Indonesia in PBI No. 6/9/PBI/2004 at $8 \%$. From the available data, the lowest (minimum) CAR value is $10.74 \%$. While the highest (maximum) CAR value is $100.63 \% 6$. From the available data, the CAR variable has an average value of $21 \%$, it shows that the average CAR value in the bank during the observation period is above the standard set by Bank Indonesia. The standard of deviation shows a value of $14.75 \%$, so that the CAR data can be said to be good because the standard of deviation value is lower than the average value.

Financing Deposit Ratio (FDR) variable has the standard set by Bank Indonesia in PBI No. 6/9 / PBI/2004 at 85\% -110\%. From the available data, the lowest (minimum) FDR value is $74.14 \%$. While the highest (maximum) FDR value is $271.88 \%$. From these data, it can be seen that FDR has an average value of $96.70 \%$, indicating that the average FDR value of 
banks during the observation period has already been on the standard set by Bank Indonesia. The

standard of deviation shows a value of $24.65 \%$, so the FDR data can be said to be good because the standard of deviation value is lower than the average value. Operating Income Operating Costs (OCOI) variable has the standard set by Bank Indonesia in PBI No. 6/9 / PBI / 2004 which is less than 92\%. From the available data, the lowest (minimum) OCOI value is $50.76 \%$. While the highest (maximum) value is $134.10 \% 7$. From the data shown, it can be seen that the average OCOI ratio is $83.27 \%$, it shows the average OCOI value for banks during the observation period is in the safe standard set by Bank Indonesia. The OCOI variable has a standard of deviation of $11.46 \%$, so that OCOI data can be said to be good because the average value is above the standard of deviation value.The Allowance for Productive Current Assets (APCA) variable has the standard set by Bank Indonesia in the Decree of Bank Indonesia Directors with the maximum value of $100 \%$.

From the available data, the lowest (minimum) APCA value is $35.90 \%$. While the highest (maximum) value is $138.53 \%$.From the data shown, it can be seen that the average value of the APCA ratio is $104.99 \%$. The value indicates that the average value of bank APCA during the observation period is above the standard set by Bank Indonesia. The APCA variable has the standard of deviation value of $11.80 \%$, so that the data from the APCA variable can be said to be good because the standard of deviation value is lower than the average value. Non Perfirming Finance (NPF) variable has standard values of Bank Indonesia regulations No. 6/9 / PBI / 2004 which is under 5\%. From the available data, the lowest (minimum) NPF value is 0 . While the highest (maximum) value is $6.76 \%$. From the data displayed, it can be seen that the average NPF value is $2.54 \%$. It shows that the average NPF value of the bank during the observation period is below the maximum standard set by Bank Indonesia. The standard of deviation of $1.57 \%$ shows that NPF data can be said to be good because the standard of deviation value is lower than the average value.

\section{Multivariate Analysis}

All independent variables significantly affect the structure at the level of a $=5$ percent reflected in the $\mathrm{F}$ test $=165.06$ with the probability of the $\mathrm{F}$ test $=0.000<0.05$. The structure of the Islamic banking industry is influenced by market share, financing level, ads intensity, 
banking profit performance, capital intensity, and dummy variables of macroeconomic conditions. The coefficient of determination $(\mathrm{R} 2)=0.984$, which means that variations in the value of the structure can be explained by variations in all independent variables by 98.4 percent. The estimation results of concentration determinants using the $t$ test at the level of a $=1$ pereent appears that only market share variables have the signifieant effeet on the structure. The coefficient of market share of 1.05 indicates that an increase in the share of one percent will increase the concentration by 1.05 percent.

$$
\begin{gathered}
\pi i t=13.262+0.078 \text { CRit }-0.038 \text { MSit }+0.001 \text { ADVitI }+0.012 \text { FDRit }+0.118 \\
+0.002 \text { COR }-0.161 \beta \text { OPitO }-0.357 \text { Dit }
\end{gathered}
$$

$$
R 2=0.814
$$

$$
F-\text { stat }=11.14 \text { Prob } F=0.00
$$

Note: $* * *=$ significant at level $\mathrm{a}=1 \%$ $* *=$ significant at level $\mathrm{a}=5 \%$

$*=$ significant at level $\quad \mathrm{a}=10 \%$

The increasing of market share and concentration means reducing competition, where the market will be less competitive. Likewise, the intensity of advertising has significant effect and its coefficient is positively marked, meaning advertising will increase market concentration. While financing expansion and capital intensity have negative coefficients, they are not significant but they have the potential to reduce concentration. The coefficient profitability (ROA) is positive but not significant which means it can potentially increase concentration. While the dummy variable which is economic condition negatively and significantly marked at level $\mathrm{a}=10 \%$, meaning that the structure at the time of crisis is different from normal conditions, where crisis conditions have the potential to reduce concentration.

\section{Behavior Determinant Analysis}

Based on the $\mathrm{F}$ test $=3.038$ with $\mathrm{F}$ Probability $=0.01<0.05$, all independent variables influence the behavior of the Islamic banking industry. The determinants of the Islamic banking industry behavior include concentration, market share, the interaction of structure and market share, the level of Islamic financing, capital intensity, and efficiency. The determination coefficient value $(\mathrm{R})=0.355$, which means that variations of the structure 
value can be explained by variations in all independent variables by 35.5 percent. The estimated results of the behavior determinant are as follows. 
A D VitI $=-134.861+1.200$ CRit-8.015MSDit + 0.159MSCitR + 1.533FDRit + 15.542CORit + 0.412ßOPitO

$\mathrm{R} 2=0.356$

$\mathrm{F}-$ stat $=3,038$ Prob $\mathrm{F}=0.02$

Note: $* *=$ significant at level $\mathrm{a}=5 \%$

$*$ = significant at level $\mathrm{a}=10 \%$

\section{The Applicability of SCP Relations}

The relationship analysis of structure, behavior and performance is modeled in the SCP hypothesis. Three hypotheses that can be tested are structure-performance hypothesis (traditional SCP), differentiation hypothesis (DTH), and efficiency hypothesis (ECH). Based on the $\mathrm{F}$ test $=11,136$, with $\mathrm{F}$ Probability $=0,000<0.05$, it means that all determinants of profitability performance (ROA) have real effect. The coefficient of determination (R2) of 0.813 means, 81.3 percent of the profitability variation is explained by the independent variables variations in the model. However, based on the t test, only one determinant has significant effect on the level of $\mathrm{a}=1$ percent, the others do not have significant effect at either the 5 percent level or the 10 percent level. The SCP estimation model is written as follows;

nit $=13.262+0.078$ CRit-0.038MSit +0.001 ADVitI +0.012 FDRit +0.118 NPFit

$$
\begin{aligned}
\hline R 2=0.814 & -0.002 \text { CORit }-0.161 \beta \\
F-\text { stat } & =11.14 \text { Prob } F=0.00 \\
\text { Note: } * * * & =\text { significant at level } \mathrm{a}=1 \% \\
* * & =\text { significant at level } \mathrm{a}=5 \% \\
* & =\text { significant at level } \mathrm{a}=10 \%
\end{aligned}
$$

Positive but not significant concentration coefficients, and negative market share coefficients are also not significant, meaning that the determinant of the structure does not affect the performance of Islamic banks in earning profits. The behavior coefficient, namely the intensity of advertising and the management of financing risk is positive but not significant, 
meaning that the determinant of behavior also does not affect the performance of bank profitability. The only determinant that has significant influence on earnings performance is efficiency. The positive OCOI coefficient is -0.161 , meaning that the greater the ratio of operating costs to operating income, or the more inefficient will reduce the ability of banks to earn profit. An efficient Islamic bank will be able to obtain high profitability. Based on this, the proven hypothesis is the efficiency hypothesis, where the profit performance of the Islamic banking industry is caused by efficiency not due to the collusion of the oligopolists and their behavior. Sources of efficiency are driven by differentiation which affects the increase of market share and the ability of banks to maintain risk as well as to obtain income and profits.

\section{DISCUSSION}

Another significant determinant of banking performance variable (ROA) in this study is the capital adequacy ratio (CAR) which has significant positive effect. The positive relationship between CAR and ROA shows that the smaller the risk has an effect on increasing profitability, because the greater the CAR, the lower the risk of a bank. Given the important role of CAR and its significant positive effect on profitability, it is very important to maintain its own capital position with risk assets in CAR position of at least 12 percent. CAR is one of the usual regulatory policies to maintain the stability of the banking sector. Given the role of CAR that cannot be ignored, capital regulation policies for the purpose of strengthening bank resilience to risk, regulations on transparency of financial statements, quality improvement of the good organizational governance implementation, and the improvement of risk management effectiveness need to be improved. The policy of restructuring the level of competition in the Islamic banking industry needs to be done by re-establishing the banking structure that harmonizes the scale of business with capital requirements, in order to enhance the ability to absorb business risks.

The market structure of the Islamic banking industry in Indonesia is oligopoly. However, in the period of study, there has been a change in the structure of oligopoly into monopoly competition (2015-2018). The performance of the Islamic banking industry is well, measured by the profitability. This shows that the Islamic banking industry in this study were represented by 16 Islamic commercial banks and 24 Islamic Business Units which controlled more than 75 percent of the total market share.

The increasing concentration was also supported by the existence of the policy to strengthen the capital structure in accordance with the direction of API policies to strengthen the capital 
structure. In addition to improve the capital structure, Islamic banks will also reduce competition level so that banks will be more flexible in carrying out their business activities. With the decreasing competition level, the operating banks can easily increase their profitability by implementing a strategy of interest rates equality. So the increasing level of profitability that is influenced by the increasing market concentration reflects that the Islamic banking industry is efficient.

\section{CONCLUTION}

The conclusions that can be used as information and input material both for the regulators and for the doers in the Islamic banking industry, is that concentration has significant positive effect on profitability, so banks as business entities can behave efficiently thus the increasing market share can increase profitability. The findings in this study are as information and input material for bankers or actors in the Indonesian banking industry to be able to behave efficiently (by reducing operating costs including funding costs and risk premiums) so as to produce good performance with increasingly good levels of profitability and stability maintained in the future. Given the importance of healthy competition to support the creation of an efficient banking industry, in addition to prudential regulation to prevent the increasing risk of crises and protective regulations such as the establishment of the Deposit Insurance Corporation (DIC) to protect customers, competitive regulation policy is needed.

The Islamic banking industry should continue to improve efficiency, expand market share, expand financing, and maintain the existing market segments. For this reason, the role of the government as the regulator is very important in monitoring and making policies that support the creation of healthy and efficient banking industry so that the role of the banking industry is as the source of financing for development. The market structure of the oligopoly Islamic banking industry provides greater opportunity for banks to act collusively that benefits the community as customers. Oligopoly or high concentrated market structure as the result of capital regulations as the Indonesian Banking Architecture program has proven increasing profitability as the measurement of performance, but objective and fair supervision functions should be improved so that collusive actions do not harm the public and only give benefit for the bank as business entity.

This is related to the important role of banks as intermediary institutions. Regardless of whether the supervisory function is still carried out by Bank Indonesia or later by other institutions, it is expected that supervision toward the banking industry will be fair and 
objective, firm in enforcing the rules including the implementation of sanctions for them violating the agreed rules so that there is not mistake occur in making policies.

The results of the study that place Structure Conduct Performance in the Islamic banking sector into Oligopoly markets are in line with the research conducted by Hadad, Santoso, and Mardanugraha's research (2013) which also concludes the same results that Islamic banking enters a monopolistic market. This research finally corroborates previous studies conducted by Muhamad, Hassan, and Badar (2014) and Johnes, Izzeldin, and Pappas (2014) which state that the efficiency differences between Islamic banks and conventional banks in GCG member countries use the financial ratio approach. and Islamic banking will be able and able to earn income if the existing market system has the character of an oligopoly market in a condition of balanced competition.

\section{RECOMMENDATIONS}

Based on the findings above, the following recommendations are suggested: Islamic Bank capitalization should be encouraged so that bank performance can be enhanced. Islamic Banks should therefore be encouraged to look beyond local market and strategically expand their operations to other geographical markets and sectors of the economy. In conjunction with branch expansion, Islamic bank should consider diversification of their product portfolio. In this way Islamic banks can leverage on their assets to offer other ancillary services and maximize returns, since Islamic bank size is positively related to performance from this and other studies. Islamic Banking industry concentration negatively impacts on profitability implying that banks are not being efficient and innovative. Thus, the Islamic banking sector should be further liberalized to allow investors to come in. This will not only induce competition but add value to services rendered to customers.

Efficient and effective liquidity management should be adopted by bank managers to ensure that banks do not become insolvent. Since banks are less profitable with less liquid assets, bank managers should be encouraged to embark on extensive deposits mobilization and invest in more financial assets. This will not only improve bank profitability but it will also enable banks meet their short term obligations as they fall due. It is possible that liquid bank assets are more profitable due of some market inefficiency. Further empirical study will be required to establish this fact.

\section{FUTURE RESEARCH}


This study only covers the structure, conduct and performance of Islamic banks; this could be extended to cover many others variables and different economies from different perspective.At last, we recommend that more research be done for authoritative statements regarding the concentration andprofitability relationships. Future research will hopefully provide additional evidence on the matters focused inthis study, particularly, those among profitability, market share, and market concentration in Islamic bankingIndustry. This research must be carried out continuously because developments in the banking sector are very dynamic. For this reason, it is necessary to conduct further research on the implications of the Islamic banking structure on policies carried out by Bank Indonesia (monetary authority) to maintain the stability of the financial and monetary sectors.

\section{REFERENCES}

Afiatun, Pipit and Sudarso Kaderi Wiryono. 2016. "Efficiency and Productivity of IndonesianIslamic Banking". Journal of Technology Management. Vol 9 No.3. Pp. 264-274.

Amirillah, Muhammad Afif, Efficiency of Sharia Banking in Indonesia in 2011-2015. Master's thesis published. Post-graduate program in UNDIP FE. 2015

Astiyah, Siti and Jardine A. Husman (2016), "Intermediation Function in Banking Efficiency in Indonesia: Deviation of Provit Functions", Bulletin of Monetary Economics and Banking, Volume 8, No. 4, pp. 529-543, Bank Indonesia, Jakarta.

Ascarya, Diana Yumanita. 2012. "Comparing The Efficiency of Islamic Banks in Malaysia and Indonesia". Bulletin of Monetary and Banking Economics, IAEI Team. Pp. 95-119.

Coelli T.J, A Guide to DEAP Version 2.1: A Data Envelopment Analysis (Computer) Program, No. 8/96. Center for Efficiency and Productivity Analysis of the Econometric Department of the University of New England Armidale, NSW, 2351. 2012.

Hadad, Santoso, and Mardanugraha (2013), "Efficiency Analysis of Islamic Banking Techniques in Indonesia with Structural Conduct Performance (SCP) Methods", Research Paper, no. 7/5, Bank Indonesia Financial System Stability Bureau.

Hadinata, Ivan and A. H Manurung. 2012. "Application of Data Envelopment Analysis to Measure Performance Efficiency of Stock Funds".

Hassan, M.Kabir, Cost, Profit and X-Efficiency of Islamic Banks in Pakistan, Iran and Sudan. International Seminar on Islamic Banking Risk Management, regulation and Supervision Jakarta, Indonesia. October 2013.

Huri, M. D. and Indah Susilowati. 2014. "Measurement of Relative Efficiency of Banking Issuers with Data Envelopment Analysis (DEA) Method (Case Study: Banks Listed on 
the Jakarta Stock Exchange in 2002)". Journal of Development Dynamics, Vol. 1 No 2 p. $95-110$.

Iqbal, Ahmad, Comparison of the efficiency of Islamic commercial banks (BUS) and conventional commercial banks (BUK) in Indonesia using the stochastic frontier approach. (SCP). 2011

Johnes, Jill. Et al. 2014. "Efficiency in Islamic and conventional banks: A comparison based on financial and data envelopment analysis". Journal Department of Economics Lancaster University. Thing 1-45.

Lie, C. L. and Lih A. T. 2015. "Application of DEA and SCP on the Measurement of Operating Efficiencies for 27 International Container Ports". Paper in the Proceedings of the Eastern Asia Society for Transporation Studies, Vol. 5, p. 592-607. Taiwan

Muharam and Pusvitasari. 2012. "Efficiency Comparative Analysis of Islamic Banks with Data Envelopment Analysis Method (2012 period)". Journal of Islamic Economics and Business, Vol.2 No.3.

Mulyadi. 2000. Cost Accounting, Issue 5. Yogyakarta: Aditya Media.

Daughter, Vicky Rahma and Niki Lukviarman. 2014. "Measurement of Commercial Bank Performance with Efficiency Approach: Study of Go-Public Banking in Indonesia. JAAI. Vol 12 No.1. Pp. 37-52

Pratikto, Heri and Iis Sugianto, Performance of Islamic Bank Efficiency Before and After the Global Crisis Based on Data Envelopment Analysis, Malang. 2011

Qureshi, Muhammad Azeem. 2012. "Efficiency of Islamic and Conventional Banks: A Nonparametric Approach". International Journal of Business and Management. Vol 7 No.7. Thing 40-50.

Rosyadi, Imron and Fauzan, Comparative Efficiency of Islamic Banking and Conventional Banking in Indonesia, Journal of Management and Business. Surakarta. 2011

Sufian, Fadzlan. 2012. "The Efficiency of Islamic Banking Industry in Malaysia: Foreign vs Domestic Bank". Humanomics, Vol. 23 No. 3 things 174-192: Emerald Publishing Group Limited.

Sutawijaya, A. and Lestari, E. P. 2014. "Efficiency of Indonesian Banking Techniques After the Economic Crisis: An Empirical Study of the Application of the SCP Model". Journal of Development Economics, Vol. 10 No.1.

Yudhistira, Donsyah. 2013. "Efficiency In Islamic Banking: An Empirical Analysis of 18 Banks". United Kingdom: Department of Economic, Loughborough University, Leicestershire. 


\section{ATTACHMENTS}

Table 1

The List ofIslamic Commercial Bank (SCB) Sample

\begin{tabular}{|c|l|c|l|}
\hline & \multicolumn{1}{|c|}{ Annotation } & & \multicolumn{1}{|c|}{ Annotation } \\
\hline 1. & PT. Bank Syariah Mandiri & 9. & PT. Bank Victoria Syariah \\
\hline 2. & PT. Bank Syariah Muamalat & 10. & PT. Bank Central Syariah \\
\hline 3. & PT. Bank Syariah BNI & 11. & PT. Maybank Indonesia Syariah \\
\hline 4. & PT. Bank Syariah BRI & 12. & PT. Bank Ekspor Indonesia \\
\hline 5. & PT. Bank Syariah Mega & 13. & PT. Bank Bukopin \\
\hline 6. & PT. Bank Jabar dan Banten & 14. & PT. Bank IFI \\
\hline 7. & PT. Bank Panin Syariah & 15. & PT. Bank Rakyat Indonesia \\
\hline 8. & PT. Bank Syariah Bukopin & 16. & PT. Bank Lippo \\
\hline
\end{tabular}

Source: Statistics of Bank Indonesia.

Table 2.

The ListofIslamic Business Unit (SBU) Sample

\begin{tabular}{|c|l|c|l|}
\hline & \multicolumn{1}{|c|}{ Annotation } & & \multicolumn{1}{|c|}{ Annotation } \\
\hline 1. & PT. Bank Danamon & 13. & PT. BPD Riau \\
\hline 2. & PT. Bank Permata & 14. & PT. BPD Sumsel \\
\hline 3. & PT. Bank Internasional Indonesia & 15. & PT. BPD Kalsel \\
\hline 4. & PT. CIMB Niaga & 16. & PT. BPD Kalbar \\
\hline 5. & Hongkong Shanghai Banking Corp. & 17. & PT. BPDKaltim \\
\hline 6. & PT. Bank DKI & 18. & PT. BPD Sulsel \\
\hline 7. & PT. BPD Daerah Istimewa & 19. & PT. BPD Nusa Tenggara Barat \\
\hline 8. & PT. BPD Jawa Tengah (Jateng) & 20. & PT. Bank Tabungan Negara \\
\hline 9. & PT. BPD Jawa Timur (Jatim) & 21. & PT. Bank Tabungan Pensiunan \\
\hline 10. & PT. BPD Banda Aceh & 22. & PT. Bank OCBC NISP \\
\hline 11. & PT. BPD Sumut & 23. & PT. Bank Sinar Mas \\
\hline 12. & PT. BPD Sumbar & 24. & PT. BPD Jambi \\
\hline
\end{tabular}

Source: Statistics of Bank Indonesia. 